\title{
PERANAN HARUN BIN SAID SEBAGAI TOKOH PEJUANG DALAM KONFRONTASI INDONESIA MALAYSIA (1963-1968)
}

\author{
${ }^{1}$ Monica Lawrence Sibuea, ${ }^{2}$ Bunari, ${ }^{3}$ Asyrul Fikri \\ ${ }^{1,2,3}$ Program Studi Pendidikan Sejarah Universitas Riau \\ ${ }^{1}$ monica.lawrence1009@ student.unri.ac.id
}

\begin{abstract}
Abstrak
Tokoh yang menjadi salah satu pahlawan dalam konfrontasi Indonesia-Malaysia adalah Harun Bin Said yang merupakan anggota Korps Komando Operasional Angkatan Laut. Melakukan sabotase dan meledakkan gedung MacDonald House sebagai salah satu gedung penting di Singapura. Namun sayang karena diduga sebagai bentuk kegiatan terorisme, Harun pun dihukum gantung oleh pemerintah Singapura. Penelitian ini akan membahas tentang (1) Latar belakang kehidupan Harun bin Said hingga bergabung dalam KKO; (2) Peranan Harun bin Said sebagai tokoh pejuang dalam Konfrontasi Indonesia Malaysia 1963-1968; dan (3) Akhir perjuangan Harun bin Said dalam Konfrontasi Indonesia Malaysia 1963-1968. Pada penelitian ini, peneliti menggunakan metode sejarah dengan empat tahapan yakni heuristik, kritik, interpretasi, dan historiografi. Pengumpulan sumber diperolah dari Kearsipan Negara Republik Indonesia, Perpustakaan Korem 031/Wira Bima Kota Pekanbaru, Perpustakaan Umum dan Kearsipan Kota Pekanbaru, Perpustakaan Wilayah Soeman H.S Pekanbaru, Perpustakaan Kota Batam, Perpustakaan BP Batam dan Kantor Legiun Veteran Republik Indonesia Kota Batam. Serta melakukan wawancara kepada keluarga, para tentara dan sukarelawan operasi Dwikora. Hasil penelitian menunjukkan bahwa Harun bin Said merupakan pahlawan pejuang dalam konfrontasi Indonesia-Malaysia yang melakukan sabotase melalui misi rahasia ke Singapura pada operasi Dwikora.
\end{abstract}

Kata Kunci: Ganyang Malaysia, Harun bin Said, Konfrontasi Militer.

\begin{abstract}
The figure who becomes one of the heroes in a confrontation Indonesia-Malaysia is Harun bin Said who is a member of Operational Command Corps of the Marine. Bravely sabotage and blew up the MacDonald House building as one of the most important building in Singapore. This research will discuss about: (1) The background of the life of Harun bin Said until joining to Operational Command Corps of the Marine; (2) The role of Harun bin Said as a fighter figure in the 1963-1968 Indonesia-Malaysia Confrontation; and (3) The end of Harun bin Said struggle in the confrontation of Indonesia Malaysia 1963-1968. In this study, research used the historical method with four stages namely is heuristics, criticism, interprets, and historiography. The collection of sources was obtained from the Republic of Indonesia National Archives, Pekanbaru City Korem 031/ Wirabima Library, Pekanbaru City Publik and Archives Library, Soeman H. S Pekanbaru Regional Library, BP Batam Library and the office of the Legiun of Veterans of The Republic of Indonesia, Batam city. As well as conducting interviews with families Harun bin Said, soldiers and volunteer for the Dwikora Operation. The results showed that Harun bin Said was warrior heroes in teh IndonesiaMalaysia confrontation who carried out sabotage through a secret mission to Singapore in Dwikora Operation.
\end{abstract}

Keywords: Ganyang Malaysia, Harun bin Said, Military Confrontation. 


\section{PENDAHULUAN}

Semenanjung Malaya merdeka sebagai Penyatuan Persekutuan Tanah Melayu dalam bentuk negara Federal dengan sistem pemerintahan Monarki Konstitusional (Wiharyanto, 2010). Malaya mencanangkan pembentukan Federasi Malaysia yakni penyatuan Malaya dengan Sabah, Serawak, Singapura dan Brunai. Pada saat itu, Sabah, Serawak, Singapura dan Brunai masih di dalam kekuasaan pemerintah Inggris. United Malays National Organization sebagai pelopor untuk di bentuknya Persekutuan Tanah Melayu (Yaakoob, 1957). Presiden Sukarno menentang pembentukan karena mengganggap bahwa Federasi Malaysia akan melahirkan kolonialisme Inggris dengan desain baru yang kedepannya dapat mengkhawatirkan revolusi Indonesia yang belum selesai (Poesponegoro \& Notosusanto, 2012). Diduga federasi ini adalah rekayasa Blok Barat untuk kembali menancapkan kekuasaan di Asia Tenggara. Hal ini dapat membuat posisi Indonesia terkepung pada wilayah kekuatan baru kolonialisme yang disebut Neo-Kolonialisme (Roso, 2013).

Pada tanggal 16 September 1962, Federasi Malaysia dinyatakan resmi berdiri. Kemudian tepat pada keesokan harinya yakni pada 17 September 1963, Indonesia pun secara resmi memutuskan hubungan diplomatik dengan Malaysia. Akibat dari masalah ini, timbul demonstrasi anti-Indonesia di Kuala Lumpur dengan menyerbu KBRI, merobek-robek foto Sukarno, membawa lambang Garuda Pancasila dan memaksa Perdana Menteri Tengku Abdul Rahman untuk menginjak lambang Garuda Pancasila. Tentu saja Presiden Sukarno menjadi murka karena lambang Garuda Pancasila diinjak-injak. Oleh sebab itu dilancarkanlah sebuah gerakan yang dikenal dengan sebutan "Ganyang Malaysia”.

Sukarno pun membuat sebuah propaganda dihadapan seluruh rakyat Indonesia. Lalu lahirlah juga demonstrasi anti-Malaysia dengan membawa spanduk-spanduk bertuliskan “Ganyang Malaysia", “Gantung Tengku Abdul Rahman antek Neokolonialisme”. Para demonstran pun turut membakar kedutaan besar Inggris di Jakarta merebut kedutaan Singapura di Jakarta dan juga rumah diplomat Singapura. Sukarno mengomandankan gerakan sukarela. Diadakan sidang Komando Operasi Tertinggi di Istana Merdeka. Adapun tugas gerakan sukarela ini adalah sebagai operasi pengamanan pada bidang konfrontasi terhadap unsur kolonialisme serta pengamanan terhadap pelaksanaan program ekonomi.

Pada 3 Mei 1964, Sukarno mencanangkan pembentukan Dwi Komando Rakyat yang bertugas untuk memperkuat ketahanan revolusi Indonesia juga untuk membantu perjuangan revolusioner rakyat Malaya, Singapura, Sabah, Serawak dan Brunai. Pada 3 Mei 1964, Sukarno mencanangkan pembentukan Dwi Komando Rakyat yang bertugas untuk 
memperkuat ketahanan revolusi Indonesia. Federasi ini dibentuk sebagai bentuk kesepakatan antara golongan nasionalis dengan kerajaan Inggris. Sehingga dalam pembentukannya masih banyak front yang menentang federasi seperti Front Sosialis Malaya yang didalamnya tergabung Partai Rakyat Malaya, Partai Islam Malaya dan Partai Buruh, Barisan Sosialis, Partai Rakyat dan Partai Pekerja, Partai Rakyat Brunai dan Serawak United People's Party. Sehingga tujuan pembentukan Dwi Komando Rakyat bukan hanya untuk memperkuat pertahanan Indonesia, namun juga untuk membantu perjuangan rakyat yang menolak pembentukan federasi yang tidak menerima akan campur tangan kerajaan Inggris didalamnya.

Namun bukan berarti Presiden Sukarno membentuk Dwi Komando Rakyat untuk membangun perselisihan dengan Malaysia, namun berupa bentuk keinginan untuk mengusir Inggris dari Asia, serta meningkatkan semangat nasionalisme, militansi dan patriotisme (Budi, 2001). Ditengah situasi konfrontasi yang memanas ini, muncul seorang sosok pahlawan masa Dwikora yakni Harun Bin Said atau yang dikenal juga sebagai Harun Tohir. Harun Bin Said ditugaskan untuk melakukan sabotase ke Singapura dalam misi rahasia pada 27 Agustus 1964 berdasarkan surat SP. KKO No. 05/SP/KKO/64 dan SPD.KOTI No. 288/KOTI/8/64. Harun bersama dengan rekannya Usman Janatin yang tergabung dalam Tim Brahma dengan pemimpin yakni Kapten Laut Paulus Subekti (Citrawijaya, 2006). Harun adalah anggota Korps Komando Angkatan Laut yang rela menjadi sukarelawan Dwikora dengan jiwa patriotismenya yang siap mengemban tugas negara dengan segenap jiwa dan raga. Harun berhasil menyelesaikan tugas konfrontasi dengan sukses meledakkan gedung MacDonald House di Singapura.

Dipilihnya MacDonald House yang terletak pada jalan Orchad. Orchad Road yang merupakan pusat keramaian kota Singapura yang banyak dihuni oleh perwira, swasta Inggris dan warga asing lainnya (Herman, 1974). Namun sangat disayangkan ketika misi tersebut berhasil, Harun bersama rekannya Usman Janatin ditangkap oleh pihak kepolisian Singapura dan divonis mati dengan cara digantung. Hukuman mati ini diberikan kepada Harun karena dianggap sebagai teroris yang meledakkan bom dan mengakibatkan hilangnya nyawa, puluhan orang terluka, kerusakan hingga trauma. Disebut sebagai teroris karena saat menjalankan tugas tersebut, Harun tidak menggunakan seragam militer sehingga hukuman tidak dapat dijatuhkan hanya sebagai tawanan perang saja (Wawancara dengan bapak Herman Thio, 2021). Sedangkan di Indonesia, Harun disebut sebagai pahlawan nasional yang telah berhasil menjalankan misi rahasia tersebut atas dasar dari surat perintah Komando Operasi Tertinggi dengan seluruh tekad dan keberaniannya. 
Penelitian ini menggunakan beberapa kajian literatur sebagai pendukung penelitian. Kajian literatur adalah penelitian lain yang relevan dan merupakan penelitian sebelumnya yang dinilai cukup berkaitan dengan penelitian yang akan dilaksanakan. Juga berguna sebagai antisipasi terjadinya pengulangan terhadap penelitian dengan topik permasalahan yang sama. Penelitian yang memiliki relevansi dengan kajian tentang Singapura sudah banyak dilakukan. Penelitian dengan judul "Peranan Usman Janatin Dalam Konfrontasi Indonesia Malaysia 1964-1968” oleh Farah Ken (2013) dari Universitas Negeri Yogyakarta mengungkapkan bahwa Usman Janatin merupakan anggota Korps Komando Operasional Angkatan Laut. Bertugas untuk melaksanakan sabotase ke Singapura akibat konfrontasi Indonesia dengan Malaysia. Penelitian tentang "Konfrontasi Usman Janatin Dalam Konfrontasi Indonesia Malaysia” oleh Arif Saefudin (2017) dari Universitas Sebelas Maret menjelaskan biografi Usman Janatin dan menceritakan konfrontasi Indonesia dan Malaysia. Kemudian penelitian tentang "Perjuangan Harun Bin Said Dalam Konfrontasi Militer Ganyang Malaysia Tahun 1963-1966" oleh Nur Hasanah (2020) dari Universitas Negeri Surabaya memaparkan tentang Harun bin Said yang ditunjuk untuk berkontribusi dalam Operasi Dwikora yang akan melaksanakan aksi konfrontasi militer Ganyang Malaysia. Penelitian tersebut tentu berbeda dari kajian ini dimana belum secara khusus menjelaskan peranan Harun Bin Said sebagai tokoh pejuang dalam konfrontasi Indonesia Malaysia selama periode tahun 1963-1968. Oleh karena itu urgensi penelitian ini menjadi penting dalam mengulas peran tokoh pejuang Indonesia selama tahun 1963-1968.

Berdasarkan beberapa kajian terdahulu di atas, maka tujuan dari penelitian ini dapat dijelaskan yaitu; (1) Untuk mengetahui latar belakang kehidupan Harun bin Said hingga bergabung ke dalam Korps Komando Operasional Angkatan Laut; (2) Untuk mengetahui peranan Harun bin Said sebagai tokoh pejuang dalam konfrontasi Indonesia Malaysia; dan (3) Untuk mengetahui akhir perjuangan Harun bin Said sebagai tokoh pejuang dalam konfrontasi Indonesia Malaysia.

\section{METODE PENELITIAN}

Dalam melaksanakan sebuah penelitian maka dibutuhkan sebuah metode yang akan menjadi penentu kearah mana penelitian akan dilaksanakan, sehingga harus memilih metode yang tepat dan sistematis. Pada penelitian ini, peneliti memilih menggunakan metode penelitian sejarah. Metode sejarah adalah sebuah usaha dengan tujuan memberikan tafsiran/interpretasi untuk kejadian dimasa lalu sehingga akan mendapatkan gambaran umum 
yang akan berguna sebagai pemahaman kenyataan sejarah, perbandingan pada kehidupan saat ini dan sebagai pembelajaran dimasa akan datang (Prastowo, 2016).

Heuristik dilakukan dengan langkah-langkah yaitu; 1) Teknik Dokumentasi. Teknik ini merupakan cara mencari informasi melalui data tertulis terkait dengan topik penelitian. Pada penelitian ini menggunakan data dokumentasi berupa arsip negara dari Kearsipan Nasional Republik Indonesia dan surat pribadi yang ditulis Harun bin Said untuk keluarga. 2) Teknik Studi Pustaka. Teknik ini akan menelaah buku ataupun jurnal yang berhubungan dengan topik penelitian. Adapun perpustakaan yang dikunjungi adalah Perpustakaan Korem 031/Wira Bima Kota Pekanbaru, Perpustakaan Umum dan Kearsipan Kota Pekanbaru, Perpustakaan Wilayah Soeman H.S Pekanbaru, Perpustakaan Kota Batam, Perpustakaan BP Batam dan Kantor Legiun Veteran Republik Indonesia Kota Batam. 3) Teknik Wawancara. Merupakan pertemuan dua orang untuk bertukar informasi melalui tanya jawab sehingga dapat dibangun makna dalam suatu topik pembicaraan tertentu. Berdasarkan uraian diatas, pada penelitian yang akan menjadi narasumber adalah bapak Muhammad Salim selaku keponakan dan ahli waris dari tokoh yang akan diteliti, bapak Herman Thio pasukan KKO AL yang pernah ditahan satu sel dengan Harun bin Said ketika di Singapura, ibu Putri Kaligis sebagai komandan pasukan Kowad dalam operasi Dwikora juga menjabat sebagai ketua Legiun Veteran Republik Indonesia Kota Batam.

Setelah itu baru dilakukan kritik data untuk mendapatkan fakta dan interpretasi fakta. Semua data yang sudah diperoleh akan dikelompokkan, dianalisis dan akan uraikan dalam bentuk penjelasan yang mudah dipahami, sehingga teknik ini disebut dengan analisis data. Teknik analisis data diharapkan akan menjawab dan memecahkan masalah sehingga akan memperoleh kesimpulan sesuai dengan kebenaran yang ada. Analisis data dimaknai sebagai sebuah proses karena sudah dilaksanakan sejak awal hingga penelitian berhasil terselesaikan. Peneliti dituntut untuk dapat memecahkan masalah dengan menganalisis data yang telah dikumpulkan. Proses terakhir yang dilakukan yakni historiografi.

\section{HASIL DAN PEMBAHASAN}

\section{A. Harun Seorang Pejuang dari Bawean}

Siapa yang sangka lahirnya sosok pahlawan negara dari Pulau Bawean yang terletak di Gresik, Jawa Timur. Pulau ini dikenal dengan banyak penduduknya yang merajut asa ke Jawa bahkan sampai ke luar negeri seperti ke Singapura dan Malaysia. Yakni Harun Bin Said yang biasa dipanggil Tohir. Tohir lahir pada tanggal 14 April 1943 (Saefudin, 2018). Lahir sebagai 
anak ketiga dari lima bersaudara dari pasangan Mahdar (ayah) dan Aswiyani (ibu). Hidup dengan keluarga yang cukup sederhana bersama orangtua dan saudaranya yang lain bernama Syamsuri, Ruaidah, Asiyah dan Nawawi (Wawancara dengan Muhammad Salmi, 2021). Besar di daerah pantai membuat Harun sudah terbiasa akan kondisi cuaca yang panas dan terbiasa bermain karang di sepanjang pantai. Selain itu, kehidupan pantai mengantarkan Harun menjadi terbiasa untuk berlayar baik bersama keluarga maupun teman-temannya. Hobi berlayar yang dimilikinya di manfaatkan untuk mencari ikan guna membantu perekonomian keluarga.

Kemampuan berlayar Harun memberikan keuntungan kepadanya yakni mengetahui banyak hal pada negara-negara yang disinggahinya. Salah satunya yakni Singapura yang menjadi negara paling sering ia singgahi. Dengan berbekal kapal rute Tanjung PinangSingapura dan bermalam hingga berhari-hari menjadikan Singapura sudah tidak asing lagi di mata Harun. Pengetahuan ini yang menjadi modal untuk Harun mendaftarkan diri menjadi anggota Korps Komando Operasional Angkatan Laut. Bukan hanya berlayar ke Singapura, Harun juga pernah merantau ke Jakarta. Bersama dengan saudaranya ia berjualan es lilin untuk melanjutkan kehidupan. Bukan hanya berjuang untuk hidup, Harun juga melanjutkan pendidikan SMP di Jakarta sambil mengikuti pelatihan bahasa Inggris dan Cina.

Pada Juni 1964, Harun mendaftrakan dirinya untuk bergabung ke dunia militer dan Harun memutuskan untuk bergabung pada KKO-AL karena ia menyukai hal yang berkaitan dengan laut. Setelah menjalani pendidikan amtama, Harun berhasil meraih pangkat Prajurit KKO II (Prako). Lalu melanjutkan kembali pendidikan pada Operasi Amfibi dan Perang Hutan hingga mendapatkan pangkat yang baru yakni Kopral KKO I (Kopko I). Ketika Presiden Sukarno mengganyang Malaysia, maka dilaksanakan perekrutan dan pelatihan kemiliteran, baik dari kalangan militer sendiri maupun rakyat sipil yang akan dilatih. Salah satu dari ribuan pendaftar ini adalah Harun Bin Said. Harun terpilih untuk mendapatkan pelatihan di pulau Sambu sebagai sukarelawan Dwikora, dan bergabung dalam kesatuan tempur Operasi A/KOTI.

\section{B. Berjuang dalam Ganyang Malaysia}

Konfrontasi adalah kondisi bermusuhan antara dua belah pihak seperti negara yang terjadi akibat sebuah perbedaan kepentingan antara keduanya. Tujuan dari konfrontasi ini tentunya untuk mencapai tujuan masing-masing negara sehingga konfrontasi dipilih sebagai sarana penyelesaiannya. Adanya perbedaan pandangan dan ideologi, melibatkan konflik 
kepentingan dan adanya jalan menyelesaikan konflik merupakan sifat dari sebuah konfrontasi (Osman, 2010). Konfrontasi mempunyai pola dalam hubungan internasional atas masalah yang dipertentangkan. Melalui gerakan menyerang untuk melemahkan dan mengalahkan lawan. Namun secara umum jika dianalisis merupakan rencana yang dikomandankan pada operasi perdamaian dan dengan strategi untuk memenangkannya. Ini merupakan teknik yang masuk akal dan teratur, juga dapat dipertahankan untuk memenangkan konflik melalui pertempuran (Howard, 1999).

Presiden Sukarno mengumandangkan pidato Dwi Komando Rakyat untuk melaksananakan Pengganyangan terhadap Malaysia. Adapun isi pidato tersebut berupa ajakan untuk seluruh rakyat Indonesia turut andil dalam memperkuat pertahanan Indonesia dan membubarkan federasi tersebut (Kansil, 1972). Konfrontasi antara Indonesia dan Malaysia adalah konflik militer bersenjata yang terjadi pada tahun 1963-1968 akibat dari pembentukan sebuah federasi yang melibatkan beberapa daerah yakni Malaya, Sabah, Sarawak, Brunai dan Singapura yang berdiri pada 16 September 1963 (Oktorino, 2018). Pemerintah mempersiapkan pasukan lengkap untuk darat, laut, dan udara yang akan berjaga hingga wilayah perbatasan. Dengan melakukan pelatihan hingga merekrut sukarelawan dari rakyat sipil yang akan dilatih secara militer. Selanjutnya dilakukan pengiriman anggota ke daerah Kalimantan Utara. Lalu dibentuk 3 kelompok pasukan, yakni pasukan Sabah dan Serawak, pasukan selanjutnya yakni pasukan Kepulauan Riau dan pasukan terakhir adalah pasukan yang akan disebar ke wilayah Kalimatan Barat hingga Timur. Seluruh pasukan berada dibawah kepemimpinan Komando Operasi Tertinggi (KOTI) (Arsana, 2014).

Salah satu pejuang yang ikut serta dalam pengganyangan tersebut adalah Harun bin Said. Setelah menyelesaikan pendidikan hingga mendapatkan pangkat Kopral KKO-AL, Harun dikirim untuk melaksanakan penelitian di Pulau Sambu. Harun bergabung dalam kesatuan tempur Operasi A/ KOTI. Karena memiliki pengetahuan seluk beluk Singapura, Harun dipilih sebagai anggota yang akan melaksanakan sabotase ke Singapura. Pengetahuan yang dahulu didapat Harun saat remaja yakni berlayar menangkap ikan, juga di dukung dengan mimik wajah Harun seperti orang Tionghoa serta memiliki kemampuan berbahasa Inggris dan Cina yang diperoleh saat merantau ke Jakarta. Karena kemampuannya ini, sangat membantu dalam melaksanakan misi intelejen yang sudah beberapa kali menyamar sebagai seorang pelayanan dapur ke Singapura.

Komandan Operasi Tertinggi dibentuk pada tanggal 19 Juli 1963 yang diatur dalam Keputusan Presiden Panglima Tertinggi ABRI No. 142 Tahun 1963. Tugas pokok dari KOTI 
adalah melakukan operasi untuk mengamankan seluruh program pemerintahan seperti mengatur keamanan selama proses konfrontasi berlangsung serta pengamanan pada bidang ekonomi agar perekonomian negara tetap stabil (Citrawijaya, 2005). Harun bin Said tergabung dalam Operasi A/KOTI. Pada tanggal 27 Agustus 1964, Harun ditempatkan pada misi rahasia ke wilayah basis II yakni Singapura dengan sub-basis X yakni di Pulau Sambu berdasarkan Surat Perintah KKO No.05/SP/PMS/KKO/64 dengan SPD. KOTI No. 288/KOTI/8/64 (Saefudin, 2017). Berangkat bersama rekan-rekan lainnya, Harun menuju Pulau Sumba di bawah kepemimpinan Kapten KKO-AL Paulus Subekti.

Memulai keberangkatan dari Pulau Sambu. Saat ini Pulau Sambu termasuk kedalam provinsi Kepulauan Riau. Harun bertugas bersama rekannya Usman Janatin dan Gani. Misi rahasia yang akan dilaksanakan yakni melakukan sabotase pada pihak militer Inggris yang ada di Singapura dan melakukan infiltrasi. Ternyata pemerintahan Singapura sudah mempersiapkan penjagaan yang sangat ketat baik di darat maupun laut. Agar penyusupan ini berjalan dengan lancar, ketiganya sepakat untuk mengganti nama asli mereka. Ini bukan pertama kalinya mereka menyusup ke Singapura, karena sebelumnya sudah pernah melakukan penyusupan sebagai seorang pedagang yang datang menggunakan perahu kecil. Dengan cara inilah mereka berhasil memperoleh informasi penting. Terhitung mereka dapat keluar masuk Singapura dan kembali ke kesatuan sebanyak 2 kali (Ibrahim, 1993).

Penyusupan ketiga ini tentunya bukan hanya sekedar mencari informasi belaka. Melainkan menjalankan misi yang sebenarnya. Misi tersebut dilaksanakan pada 8 Maret 1965 pada malam hari, dengan membawa 12,5 kg bahan peledak (Mabes TNI, 2014). Ketiganya menyusuri Selat Malaka dibawah gelapnya malam menggunakan perahu. Bukan perjalanan yang mudah karena perairan Singapura di jaga ketat oleh kepolisian. Namun perjuangan mereka tidak sia-sia karena mereka selamat memasuki kota Singapura. Keesokan paginya, ketiganya membagi tugas pengintaian yang disebar dibeberapa titik sasaran berbeda. Hasil dari pengintaian tersebut akan dilaporkan pada saat pertemuan di satu titik rahasia yang telah disepakati. Tujuan pengintaian tersebut adalah untuk mendapatkan lokasi yang tepat sebagai sasaran yang mungkin dapat dihancurkan. Mereka harus memilih sasaran tepat seperti objekobjek vital di kota Singapura yang dapat menimbulkan ketidak tenangan kepada masyarakat Singapura.

Namun ternyata pengintaian pertama tidak membuahkan hasil karena ketiganya belum menemukan tempat yang cocok. Awalnya mereka akan melakukan pengeboman pada pipa air yang terbentang di pinggir laut Singapura. Namun hal tersebut tidak mereka sepakati karena 
perjalanan mereka ke Singapura bukan untuk meledakkan laut (Wawancara dengan bapak Herman Thio, 2021). Sehingga ketiganya kembali mencari daerah yang di rasa tepat. Setelah mencari mereka kembali merundingkan kesepakan dan setuju untuk meledakkan gedung MacDonald House yang terletak di Orchard Road. MacDonald House merupakan sebuah gedung setinggi 10 lantai yang sudah berdiri sejak tahun 1949 (Murgiyanto, 1989). Alasan dipilihnya gedung ini karena terletak di pusat keramaian yang juga banyak ditinggali oleh para petinggi-petinggi Inggris. Mereka menduga dengan menjadikan daerah tersebut sebagai saaran peledakan, maka dapat memberi efek hingga ke ibukota Inggris yakni London.

Pada sore harinya mereka masih melakukan pemantauan di sekitar gedung tersebut untuk memantapkan aksi mereka. Ketika malam hari tiba, keadaan Orchard Road sangat ramai sehingga tidak memungkinkan untuk melancarkan misi tersebut. Melihat keadaan jalanan sudah mulai sepi, akhirnya mereka melancarkan aksi tersebut pada dini hari yakni di pukul 03:07 pada tanggal 10 Maret 1965 (Hamid, 2015). Disaat itulah terdengar ledakan dahsyat yang tentunya membuat semua orang panik ketakutan. Ledakan ini membobol lift dan menghancurkan jendela hingga bangunan seratus meter ke depan. Hancur berkeping-keping bangunan dari MacDonald House tersebut hingga merusak kendaraan yang terparkir di depannya. Pertokoan terdekat juga terkena imbas dari ledakan ini. Misi ini juga memakan korban nyawa sebanyak 3 orang meninggal dan 33 terluka. Pada saat itu juga, ketiganya melarikan diri ke tempat yang lebih aman. Untuk sementara, misi ini dikatakan berhasil. Hasil pemeriksaan oleh pihak berwajib mengatakan bahwa bahan peledak yang digunakan mengandung nitrogliserin sebanyak 20 sampai $25 \mathrm{lb}$ atau setara dengan 9-11 kg (Sinnadurai, 1990).

\section{Akhir dari Perjalanan Sebuah Perjuangan}

Pada sore harinya, unit cadangan kepolisian melakukan operasi sekitar lokasi kejadian dan mengalihkan lalu lintas. Tim penjinak bom melakukan pemerikasaan dan staf kesehatan mengevakuasi para korban. Pukul 18:15 sore hari, menteri kesehatan Singapura yakni Yang Nyuk Lin mengunjungi para korban yang berada di rumah sakit. Wakil perdana menteri yakni Toh Chye mengecam serangan ini sebagai tindakan amat kejam yang tidak masuk akal (Newspaper SG, 1965). Perdana Menteri Lee Kuan Yew menyatakan kepada majelis legeslatif Singapura bahwa Indonesia telah merencanakan serangan ini sejak awal tahun 1960 sebelum adanya pengumuman resmi mengenai penetapan Federasi Malaysia (Sigapore Legeslative Assembly, 1963). 
Indonesia pun diduga menggunakan banyak pihak demi mendukung serangan ini. Indonesia memanfaatkan usaha bisnis untuk melakukan kegiatan upaya pemberontakan dalam merobohkan struktur kekuasaan negara, melakukan kegiatan pengintaian seperti pengumpulan data dan sabotase yang dilakukan oleh pihak intel ke Singapura. Adapun Indonesia juga menggunakan beberapa organisasi seperti Duma Corporation di Bussorah Street, Malaysia Indonesia Corporation di Jalan Beach dan Gerakan Ekonomi Melayu Indonesia di Johor Bahru. Adapun sabotase Indonesia di pimpin oleh kepala operasi yakni Masintan Sihombing yang merupakan mantan pejabat Konsulat Indonesia. Ia ditangkap ketika hendak melarikan diri ke Pulau Sambu (Newspaper, 1963).

Setelah berhasil meledakkan bom, mereka sepakat untuk kembali ke Pulau Sambu dengan pertimbangan tidak dapat melaksanakan misi lainnya disebabkan kondisi sudah tidak kondusif lagi. Alasan lain dikarenakan bahan peledak yang kurang. Seluruh Singapura sudah dijaga ketat karena dilaksanakan operasi pencarian pelaku pengeboman sehingga Usman, Harun dan Gani memilih untuk keluar dengan jalan berpencar, dan segera melaporkan hasil dari misi ini. Namun karena Usman tidak mengetahui daerah tersebut maka ia akan keluar bersama dengan Harun. Hingga berhasil sampai di Pelabuhan Singapura, ketiganya menyamar pada sebuah kapal dagang sebagai awak kapal tersebut. Namun penyamaran tersebut tidak berhasil karena ketahuan oleh pemilik kapal dan tidak mau menanggung resiko jika ketahuan oleh pihak kepolisian Singapura.

Usaha untuk kembali ke Pulau Sambu dilanjutkan pada keesokan harinya dengan merampas perahu warga yang ada di pinggiran laut. Namun tidak disangka, perahu tersebut mendadak mati hingga akhirnya keberadaan mereka diketahui oleh polisi air Singapura yang hendak melaksanakan patroli. Berakhirlah perjuangan Harun Bin Said sebagai pejuang konfrontasi setelah akhirnya berhasil ditangkap. Harun menjalani pemeriksaan dan dipaksa untuk mengakui kesalahan yang diperbuat. Harun bisa saja menahan diri untuk tidak mengakui misi tersebut, namun dikarenakan siksaan yang ikut diberikan yakni dengan melepas kuku-kuku secara paksa, melepas pakaian hingga menyiram badan Harun dengan bongkahan es, sehingga secara terpaksa Harun mengakui misi tersebut dilakukan olehnya (Wawancara dengan Herman Thio, 2021). Begitupun dengan Usman yang juga mengakui perbuatan tersebut. Setelah kepolisian berhasil mendapatkan informasi tersebut, maka dikeluarkanlah hukuman untuk keduanya yakni hukuman mati pada tanggal 20 Oktober 1965.

Pemerintah Inggris memberikan hukuman mati dengan cara digantung kepada Harun atas dua dasar atau alasan. Yang pertama adalah karena perbuatan kriminal yang merenggut 
nyawa orang lain akan mendapat hukuman yang setimpal yakni hukuman mati, karena begitulah adanya peraturan di Singapura saat itu (Wawancara dengan Ibu Putri Kaligis, 2021). Alasan kedua adalah karena Harun ditetapkan sebagai teroris. Harun menjalankan misi rahasia tersebut dengan menggunakan pakaian sipil (tidak menggunakan seragam militer). Sehingga dengan alasan tersebut, tindakan harun dianggap sebagai tindakan keji dan kriminal tanpa adanya perintah dari sebuah negara. Hingga menunggu pelaksanaan hukuman tersebut, Harun dibawa ke Penjara Changi. Di penjara tersebut Harun pun bertemu dengan temanteman seperjuangan yang sebelumnya sedang dalam persiapan melaksanakan aksi namun gagal. Pemerintah Indonesia tentu tidak akan membisu.

Pemerintah turut bekerja untuk mendapatkan cara agar para pejuang termasuk Harun keluar dari penjara tersebut. Pemerintah sudah menyiapkan ahli hukum untuk membela Harun namun tetap saja pembelaan tersebut gagal. Tidak sampai disitu saja, pemerintah melakukan banding sebanyak dua kali yakni pada Pengadilan Federal Malaysia dan ke Privy Council di London. Pemerintah juga mengajukan grasi kepada Presiden Singapura. Selain itu pengajuan permohonan penundaan hukuman oleh Kedutaan Besar Republik Indonesia. Namun semua usaha tersebut ditolak dan dinyatakan gagal. Dalam sistem yang ada di Singapura, sebuah kejahatan yang menghilangkan nyawa seseorang maka harus diganti pula dengan nyawa. Dan pemerintah Singapura tidak menerima negosiasi dari pemerintah Indonesia. Singapura tidak menerima kebenaran bahwasanya Harun merupakan prajurit yang sedang melaksanakan tugas negara karena tidak mengenakan atribut kemiliteran. Sehingga Harun harus tetap menjalankan hukuman mati gantung sebagai teroris bukan tawanan perang.

Hingga pada harinya yakni 17 Oktober 1968, Harun siap untuk menjalankan hukuman mati di tiang gantung. Hukuman tersebut dilaksanakan pada pagi hari pukul 06:00. Pesawat dari Indonesia diberangkatkan untuk menjemput jenazah pada pukul 14:45. Tiba di Bandara Kemayoran, penyambutan jenazah dengan upacara kemiliteran. Di semayamkan di Aula Staf HANKAM (Staf Pertahanan Keamanan), selanjutnya dimakamkan di Taman Makan Pahlawan Nasional di Kalibata pada tanggal 18 Oktober 1968. Atas jasa perjuangan untuk bangsa dan negara yang telah dilakukan Harun, menghargai sifat kepahlawanan, keberanian serta tekad yang melebihi kewajiban dalam melaksanakan tugas militer maka Harun ditetapkan sebagai Pahlawan Nasional. Selain itu juga atas jasa luar biasa hingga dijatuhi hukuman mati, Harun diberikan penghargaan berupa kenaikan pangkat satu tingkat lebih tinggi menjadi Kopral Komando Anumerta berdasarkan Keputusan Presiden Republik 
Indonesia No. 050/TK/Tahun 1968 dengan Gelar Pahlawan dan Tanda Kehormatan Bintang Sakti (Arsip Kota Surabaya, 1968).

Tidak sampai disitu, nama Harun juga telah diabadikan oleh Tentara Negara Indoneisa sebagai nama sebuah Kapal Perang Republik Indonesia, yakni KRI Usman Harun 359. Kapal ini menjadi salah satu kapal penjaga perairan Natuna utara bersamaan dengan KRI Karel Satsui Tubun 356 dan KRI Jhon Lie 358 (CNN Indonesia, 2020). Walaupun penamaan kapal ini memunculkan kontroversi terhadap Singapura yang masih trauma akan kejadian 1964, namun pemerintah Indonesia tidak menggubris hal tersebut karena penghormatan terhadap pahlawan bangsa tidak boleh ada intervensi dari negara lain. Pada Mei 2013, Presiden Joko Widodo secara resmi mengganti nama Jalan Prapatan Kwitang, Senen, Jakarta Selatan menjadi Jalan Prajurit KKO Usman-Harun. Keputusan tersebut tertuang dalam Keputusan Gubernur No. 758 Tahun 2013. Dinas Perhubungan DKI diminta untuk mengganti pelang nama jalan tersebut.

Dengan selesai dilaksanakannya hukuman mati, maka berakhirlah Konfrontasi Indonesia-Malaysia. Kedua negara ini akhirnya secara resmi menandatangani Piagam Perdamaian. Hubungan Indonesia dan Singapura belum terlalu akrab seperti sedia kala, namun ketika perdana menteri Lee Kuan Yew ingin mengunjungi Jakarta untuk bertemu dengan Presiden Suharto, Lee Kuan Yew di wajibkan terlebih dahulu melaksanakan tabur bunga pada makam Harun bin Said. Setelah itu, hubungan diplomasi Indonesia dan Singapura berangsur membaik.

\section{KESIMPULAN}

Harun bin Said atau Harun Tohir merupakan seorang pejuang Konfrontasi IndonesiaMalaysia (19630-1968) yang lahir di Pulau Bawean, Jawa Timur. Harun memutuskan untuk masuk kedalam dunia militer dan berhasil bergabung dalam Korps Komando Operasional Angkatan Laut. Melaksanakan sejumlah pelatihan khusus hingga ditunjuk untuk bergabung dalam pasukan khusus guna melaksanakan misi rahasia. Misi tersebut adalah melaksanakan sabotase ke Singapura. Harun bersama rekannya melaksanakan pengeboman pada gedung MacDonald House di Singapura. Namun sial aksi tersebut berhasil diketahui kepolisisan Singapura. Harun disebut sebagai teroris karena diduga melaksanakan tindakan keji yang merengut nyawa orang lain, serta melaksanakan misi rahasia tanpa menggunakan atribut militer, sehingga Harun tidak bisa dibeti hukuman sebagai tawanan perang. Harun dijatuhi hukuman mati dengan cara digantung. Namun Indonesia menganggap Harun merupakan 
pahlawan yang berjasa untuk negara atas tekad dan keberaniannya. Atas jasa tersebut Harun diberi penghargaan oleh pemerintah Indonesia sebagai Pahlawan Nasional dengan gelar penghormatan Bintang Sakti. Harun juga mendapat penghargaan kemiliteran berupa kenaikan pangkat satu tingkat lebih tinggi menjadi Kopral Komando Anumerta. Nama Harun pun diabadikan sebagai nama Kapal Perang Republik Indonesia dan sebagai nama jalan di Jakarta Selatan. Akhir penyelesaian dari konfrontasi ini adalah penandatanganan surat perdamaian antara Indonesia dan Malaysia.

\section{UCAPAN TERIMAKASIH}

Tidak lupa saya ucapkan terimakasih kepada semua pihak yang membantu dan mendukung saya selama melaksanakan penelitian. Pertama kepada orang tua dan keluarga yang selalu memberi saya semangat untuk menyelesaikan penelitian ini. Juga kepada para dosen yang membimbing saya dalam penulisan penelitian ini. Juga tidak lupa kepada seluruh teman dan rekan yang mempermudah saya melakukan penelitian pada daerah-daerah yang belum saya ketahui. Semoga kita semua dalam lindungan Tuhan Yang Maha Esa.

\section{DAFTAR PUSTAKA}

Arsana, Nyoman. 2014. Operasi Dwikora 1962-1966. Jakarta: Tapasuma Ratu Agung.

Arsip Kota Surabaya, Arsip tentang Kepres RI No. 050/TK/Tahun 1968 tentang Penganugrahan Gelar Pahlawan dan Tanda Kehormatan Bintang Sakti Kepada Djanatin alias Osman bin Hadji Mohamad Ali (Alm) DAN Harun bin Said alias Tahir (Alm).

Budi Jatmiko, Siswanto. 2001. Bung Karno, Bapakku, Guruku, Sahabatku, Pemimpinku, Kenangan 100 tahun Bung Karno. Jakarta: Gramedia Widiasarana Indonesia

Citrawijaya, Supoduto. 2005. Kompi X di Rimba Siglayan. Jakarta: Buku Kompas

Citrawijaya, Supoduto. 2006. Kompi X Di Rimba Sidlayan. Jakarta: Kompas

Daniel Dhakidae. 2009. Hubungan Cinta-Benci antara Indonesia dan Malaysia. Majalah Prisma, 28(2).

Fakta KRI Usman Harun di Natuna yang Bikin Jengkel Singapura. (2020, 09 Januari). CNN Indonesia. $\quad$ https://www.cnnindonesia.com/teknologi/20200109141152-199463843/fakta-kri-usman-harun-di-natuna-yang-bikin-jengkel-singapura

Hamid, Mohamed \& Saparudin. 2015. MacDonald House Bomb Explosion. Singapura: Singapura Infopedia

Herman Mujirun. 1974. Sekilas Kenangan 2(dua) Pahlawan Serda KKO Usman Bin H. Ali dan Kopral KKO Harun Bin Said. Jakarta: Yayasan Sosial Usman-Harun

Howard, Nigel. 1999. Confrontation Analysis: How to Win Operations Other Than War. Washington: CCRP Publications Series 
Peranan Harun Bin Said ..... Monica Lawrence Sibuea, Bunari, Asyrul Fikri

Ibrahim, Muchtaruddin. 1993. Usman Bin Haji Muhammad Ali alias Janatin. Jakarta: Proyek Inventaris dan Dokumentasi Sejarah Nasional

Ibrahim, Yaakoob. 1957. Sekitaran Malaya Merdeka. Kesatuan Malaya Merdeka.

Kansil, C.S.T \& Julianto. 1972. Sedjarah Perdjuangan Pergerakan Kebangsaan Indonesia. Jakarta: Erlangga

Mabes TNI. 2014. Biografi Pahlawan Nasional dan Lingkungan TNI. Jakarta: Pusat Sejarah Markas Besar Tentara Nasional Indonesia.

Murgiyanto. 1989. Usman dan Harun Prajurit Setia. Jakarta: Direktorat Perawatan Personil TNI-AL

Newspaper SG. 1965. Terror Bomb Kills 2 Girls at Bank. Singapura

NewspaperSG. 1963. Indonesia Began to Plot Long Before Malaysia was Moooted

Oktorino, Nio. 2018. Operasi Dwikora. Jakarta: PT. Gramedia

Osman, Ferdous. A. 2010. Bangladesh Politics: Confrontation, Monopoly and Crisis in Govermance. Asian Journal of Political Science, 18(3), 312.

Poesponegoro, M. D \& Notosusanto, Nugroho. 2012. Sejarah Nasional Indonesia IV. Jakarta: Balai Pustaka

Prastowo, Andi. 2016. Metode Penelitian Kualitatif dalam Perspektif Rancangan Penelitian. Yogyakarta: Ar-Ruzz Media

Roso Daras. 2013. Total Bung Karno, Serpihan Sejarah yang Tercecer. Depok: Penerbit Imania

Saefudin, Arif. 2017. Patriot Bangsa dari Kota Perwira: Biografi Usman Janatin 19431968. Jakarta: Direktorat Sejarah

Singapore. 1963. Indonesia Saboteurs and Local Fifth Columnists. Debate: Official Report, Vol. 22. Singapura: Legislative Assembly

Sinnadurai, V. 1990. The Privy Council Cases: Malaysia, Singapora, Brunai, 1875-1990. Singapura: Professional Law Books.

Wariya, C \& Yushak, Y. 2010. Malaysia: Asa Pembinaan Negara Bangsa, Institusi Pemerintahan, Lambang Kebangsaan. Malaysia: Media Global Matrix.

Wawancara dengan Herman Thio yakni teman satu sel Usman dan Harun saat di Singapura. Wawancara dilaksanakan di Batam, 9 Maret 2021.

Wawancara dengan Putri Kaligis yakni Komandan Korps Wanita TNI Angkatan Darat 1964 juga sebagai Ketua Legiun Veteran Republik Indonesia, Cabang Kota Batam dilaksanakan di Batam, 11 Maret 2021.

Wawancara via telepon dengan keluarga serta ahli waris yakni Muhammad Salim pada 23 Maret 2021.

Wiharyanto, A. Kardiyat. 2010. Filipina dan Masalah Sabah. HISTORIA VITAE: Seri Pengetahuan dan Pengajaran Sejarah. 